\title{
Evidence-based approaches to learning
}

This article was published in the following Dove Press journal:

Advances in Medical Education and Practice

\section{Ameer Hamid A Khan' \\ Sagar Kulkarni' \\ Taha Mahmood' \\ Ameena A Khan ${ }^{2}$}

'Barts and The London School of Medicine and Dentistry, London, UK; ${ }^{2}$ Department of Medicine, Imperial College London, London, UK
Correspondence: Ameer Hamid A Khan Barts and The London School of Medicine and Dentistry, Garrod Building,

Turner Street, Whitechapel, London, EI 2AD, UK

Email ha13364@qmul.ac.uk
We took great pleasure in reading the article by Aldosari et $\mathrm{al}^{1}$ about the learning style preferences of dental students. The authors showed that high-performing students preferred a multimodal style of learning. We would like to raise a few points that we feel would further guide the faculty in identifying ways of tailoring their teaching methods to the learning needs of their students.

It was interesting to note that the authors conducted a questionnaire using the VARK (Visual, Auditory, Read/write, Kinesthetic) model of learning. Belief in the VARK model is commonplace; $93 \%$ of British teachers believed that students learnt better when they received information in their preferred learning styles. ${ }^{2}$ Similar results have been observed in other countries.

However, there is currently no reliable evidence to support the use of VARK learning style preferences as an education tool. ${ }^{3}$ Individuals may prefer one or more learning styles, but there is no available evidence to suggest that matching studying methods to preferred learning styles improves educational outcomes. ${ }^{4}$

The prescriptive nature of this education tool may even be detrimental to learning as students may not engage with study techniques they perceive as being more suited to a different learning style. Similarly, students may also develop a false sense of confidence in their ability to master subjects, which they perceive match their style. Furthermore, learning styles may even deter students from techniques, which have been demonstrated to be effective. ${ }^{5}$ Examples of evidence-based learning tools that have been demonstrated to be useful include the "testing effect" and "spaced repetition".

We feel that the study findings are particularly interesting as they are supportive of a pedagogical approach that shifts away from conventional VARK learning style preferences. Students with higher grade point averages were more likely to prefer quadmodal or bimodal learning styles. ${ }^{1}$ We might expect this as students with higher academic attainment may have opted for more effective and broad-based study techniques. Similarly, we note that second-year students prefer bimodal over unimodal learning style preferences. Having successfully completed their first year at university, second-year students would have had more learning experiences at university and more time to identify an approach that works best for them.

Therefore, we agree with the authors of this study that encouraging students to use a multimodal approach would improve their learning preferences, but we feel that their study further highlights a need for educators to move away from identifying a learning preference for students to use and toward encouraging students to realize that 
the integration of multiple learning styles will help enhance their learning. 5

\section{Disclosure}

The authors report no conflicts of interest in this communication.

\section{References}

1. Aldosari MA, Aljabaa AH, Al-Sehaibany FS, Albarakati S. Learning style preferences of dental students at a single institution in Riyadh, Saudi Arabia, evaluated using the VARK questionnaire. Adv Med Educ Pract. 2018;9:179-186.
2. Dekker S, Lee NC, Howard-Jones P, Jolles J. Neuromyths in education: prevalence and predictors of misconceptions among teachers. Front Psychol. 2012;3:429.

3. Newton PM. The learning styles myth is thriving in higher education. Front Psychol. 2015;6:1908.

4. Pashler H, McDaniel M, Rohrer D, Bjork R. Learning styles: concepts and evidence. Psychol Sci Public Interest. 2008;9(3):105-119.

5. Howard-Jones PA. Neuroscience and education: myths and messages. Nat Rev Neurosci. 2014;15(12):817-824.

Dove Medical Press encourages responsible, free and frank academic debate. The content of the Advances in Medical Education and Practice 'letters to the editor' section does not necessarily represent the views of Dove Medical Press, its officers, agents, employees, related entities or the Advances in Medical Education and Practice editors. While all reasonable steps have been taken to confirm the content of each letter, Dove Medical Press accepts no liability in respect of the content of any letter, nor is it responsible for the content and accuracy of any letter to the editor.

\section{Publish your work in this journal}

Advances in Medical Education and Practice is an international, peerreviewed, open access journal that aims to present and publish research on Medical Education covering medical, dental, nursing and allied health care professional education. The journal covers undergraduate education, postgraduate training and continuing medical education including emerging trends and innovative models linking education, research, and health care services. The manuscript management system is completely online and includes a very quick and fair peer-review system. Visit http://www.dovepress.com/testimonials.php to read real quotes from published authors.

Submit your manuscript here: http://www.dovepress.com/advances-in-medical-education-and-practice-journal 